\title{
Marriage, Sexuality and Moral Responsibility among the Tongu Mafi People of Ghana ${ }^{1}$
}

\author{
Godson Ahortor \\ Lecturer, Department for the Study of Religions, \\ University of Ghana, Legon
}

\begin{abstract}
Marriage is considered a very important institution in traditional societies in Africa. It has moral and social responsibilities. Beyond the social function, this paper makes the claim that notions of marriage life, sexuality and moral responsibility have their foundations in indigenous soteriological beliefs and worldviews. A cultural and religious analysis of connubial practices of the Tongu Mafi people of Ghana reveals that marriage rites and responsibilities are not defined without reference to soteriological beliefs and worldviews of the people. The paper concludes that sanctions and corrective rituals against breaches of moral responsibility relating to marriage and sexuality usually have soteriological implications.
\end{abstract}

Keywords: marriage, sexuality, responsibility, soteriology, beliefs

It is often said among the Mafi people in Ghana that moral responsibility can be best assessed within the arena of the institution of marriage. The Mafi people are a section of the Ewegrouping referred to as the Tongu people. The Tongu people have settlements along both sides of the Lower Volta River in the southeastern part of Ghana. The Mafi people are predominantly settled

1 The author expresses his sincerest gratitude to the African Humanities Program of the American Council of Learned Societies (AHP-ACLS) and the University of Ghana, Legon for providing funds for this research. 
in the present Central Tongu District of the Volta Region even though some of their settlements can be found in parts of Ho West, South and North Tongu Districts in the same administrative region. As part of the larger Ewe community, the Tongu Mafi people share a lot in common in terms of social, cultural and religious values and practices with the larger Ewe community. However, the Tongu Mafi people have some beliefs and worldviews that are distinct and peculiar to them. The soteriological beliefs and ambitions of the Tongu Mafi as well as their conceptualisation of evil differ in details from those of the other Ewe -groupings. In Mafi thought, persons who attain the status of an ancestor or at least join the ancestors at the ancestral home are considered to have attained salvation. Therefore, the soteriological ambition of the Tongu Mafi average adult is to be an ancestor or at least join the ancestors in the hereafter. In addition, in Mafi metaphysics, salvation can also be experienced in the present existence. Salvation in the present life is captured in the expression dagbe. The etymological meaning of dagbe (deagbe) is 'to redeem life' and a 'redeemed life' has the connotation of abundant life. Dagbe or salvation in the present existence therefore corresponds to abundant life. It is a life devoid of evil and all its manifestations (Gaba, 1978, p. 392).

In Mafi philosophical thought, the qualification for attainment of salvation in both the hereafter and present existence is explained in the context of their conceptualisation of evil. Like many other ethnic groupings in Ghana, the conditions for ancestorship include living up to an old age with children, dying a natural death and living an exemplary life (Sarpong, 1971, p. 3; Dzobo, 1985, pp. 334-340). In Mafi culture, however, living an exemplary life is first and foremost living a life devoid of evil. Evil in Mafi thought is defined as the destruction or doing something that could affect the sanctity of life. Life is considered the highest value and whatever promotes and protects the sanctity of life is considered good while anything that affects it negatively is considered evil (Meyer, 1999, pp. 85-86; Ahortor, 2015, pp. 101-102). In this sense, to use spiritual or physical means to kill 
or destroy life is evil and the perpetrators are denied entry into the ancestral home and denied salvation. At the same time, their dead bodies are cremated as a punitive mortuary rite. These evildoers may be seen at times as prospering in life but they are never regarded as experiencing dagbe or salvation in the present existence (Gaba, 1978, p. 395). The realisation of salvation in both the hereafter and the present life is facilitated through rituals, especially, those that aim at preventing and overcoming the presence and effects of evil in the society. Thus conceived, ritual practices form an integral part of the cultural practices of the people.

An investigation into the socio-cultural and connubial practices of the Tongu Mafi people shows that the rituals relating to marriage, sexuality, procreation and marriage life, on the one hand, reveal different modes and attempts by which the Tongu Mafi people hedged in ethical values they cherish; and on the other, the rituals and other practices underscore how soteriological ambitions can conceptually affect individual and communal moral praxis. The moral responsibility of the married couple, family and for that matter the society thus comes clear in the arena of the institution of marriage and it flows from soteriological ambitions.

This paper identifies and analyses connubial practices of the Tongu Mafi people of Ghana. It also explores the intersections of marriage, sexuality and moral responsibility and how they are grounded in the soteriological beliefs and worldviews of the people. The framework for this study is traditional concepts and practices regarding evil. In Mafi thought, the images of evil are often presented as life-threatening. The notion of evil then seems to dictate the outlook of life and serves as a measure for moral praxis. This framework supports the view of Meyer (1999) that 'Ewe ethics can be glimpsed through the analysis of these particular images of evil' (p. 88). This paper is based on a phenomenological study of the Tongu Mafi people of Ghana, mainly through interviews with purposively selected opinion leaders and observation of routine socio-cultural practices of the people. This is part of data gathered from fieldwork conducted 
between 2010 and 2014 for a $\mathrm{PhD}$ study. It was primarily an investigation into soteriological beliefs and ethical values of the Tongu Mafi people.

Many scholars have written about marriage in Africa. Mbiti (1969) has noted that 'for the African peoples, marriage is the focus of existence' (p. 130). Many scholars have therefore devoted their writing to the types of marriages and the significance of marriage to the survival of the family and society in general. Gyekye (1996) noted that marriage is an important cultural value in the African society (pp. 76-92). Nukunya (2003) identified and examined 'three generally accepted essential elements' of marriage in Ghanaian societies (pp. 42-48). These are the marriage payment, handing over of the bride to the bridegroom and the marriage ceremony. In all these, procreation, marriage responsibilities and prohibitions in the social set-up are considered in the light of their social functions. Beyond the social functions, this paper, using the experience of the Tongu Mafi people of Ghana, explores the intersections of marriage, sexuality and responsibility and locates the foundations in the soteriological beliefs of the people.

\section{Marriage among the Mafi People}

A Mafi person can marry a person of his or her choice within or outside the Mafi society. But within the social set-up, there are permissible and non-permissible marriages. There are no restrictions to exogamous marriages. But as pointed out by Nukunya (2003), 'among the Tongu Ewe also marriages within the clan are encouraged but here very closely related members of the clan are preferred as marriage partners' (p. 20). Among the Tongu Mafi people, the preference is fomesro or 'kinship marriage'. It is within this non-exogamous marriage set-up that the rules for permissible and non-permissible marriages are outlined. Outside the permissible marriage order are the prohibited marriages. Because such marriages are not allowed, sexual relationships are equally forbidden (Nukunya, 1969, p. 67). Any 
such sexual relationship is considered evil. The categories for which sex and marriage are forbidden are as follow:

1. Father and daughter; including adopted daughters, daughters of one's wife fathered by other men and this, whether the wife is alive or deceased.

2. Mother and son; including adopted sons, sons of one's husband born to him by other women, whether this husband is alive or deceased.

3. Children of the same parents, including adopted siblings, step brothers and sisters.

4. Grandparents and grandchildren.

5. Uncle/Aunt and niece/nephew.

6. Marriage among in-laws.

7. Even in polygamous marriage, marriage to two sisters is prohibited. In the case of twin sisters, it is permissible but according to discussants it is rare in practice.

8. One cannot marry the brother's wife when the brother is alive, even when they are separated or divorced. However, after the death of an elder brother, a younger brother can marry the deceased's wife.

As stated earlier, the prohibition also entails that sexual relationships in these categories be avoided. To have sex within the prohibited categories constitutes incest. Incest is an evil act and persons involved must be sanctioned for breaching sexual prohibitions. Even if the act is kept secret, it is believed that the offenders will be spiritually punished. If they are identified, rituals must be performed to cleanse them and prevent eventual deaths in the family. One of the visible symptoms of the consequences of incest is described by Nukunya (1969) as 'a fatal pulmonary disease' (p. 69). This appears as very severe fits of hiccups.

Apart from the pulmonary disease, an incestuous person can suffer from other incurable diseases. When diviners are consulted on problems of incurable diseases, the revelations sometimes turn out to be consequences of incestuous acts committed by the patients. In most cases of incest, diviners are reluctant to announce what they see but require from the victims a confession. While the cause of the pulmonary disease is believed 
to be spiritual in Mafi thought, the start of the disease is mostly traced to social interactions. For instance, if a man has sexual intercourse with two sisters, knowingly or unknowingly, anytime one of the sisters gets sick and is visited by the other sister, it will also lead to the patient getting the pulmonary disease. Similarly, any sexual affair between persons in the prohibited categories of marriage would expose them to an attack of the disease when one of them gets sick and the other visits him or her. The cultural norm of the people imposes on them to always be socially interactive by visiting one's kin, handshaking and sympathising with others in their troubles. This norm and social practice expose victims of social misconduct, advertently or inadvertently, to the dreaded pulmonary disease. This makes incest a real threat. The base line is that incest is an evil act and the consequent attack of pulmonary disease a threat to life so when they are identified in the community, urgent steps are taken to correct the anomaly by performing the appropriate rituals.

Marriage among the Mafi Ewe in the past seemed to be a never ending-process. The search for partners, preparations for the marriage and obligations of the married couple were not limited to specific time and the ramifications of marriage were evoked even after death. My discussants distinguished three concepts of marriages in Mafi traditional communities. These are nyanunanaatsu or 'betrothal marriage', ahiasrodede or 'concubine marriage' and ahosrodede or 'widow marriage'. The ideal form of marriage practices for the Mafi people has for a long time been betrothal marriage. Normally, the lady is betrothed to the man at a tender age, sometimes even below the age of five years. This is not a mere expression of wish; families concerned with the marriage proposal must reach a mutual agreement which will later be customarily sealed with drinks. By this mutual agreement, the man and his family share the responsibility of the upbringing of the woman with her parents or family. In Mafi thought, it is explained that everyone is at liberty to marry a person of his or her choice and individuals have the freewill to accept or reject advice. However, in marriage, for instance, the youth are 
trained to obey and accept the good counsel of their parents. The youth then are obliged to accept choices made on their behalf by parents, without signs or expressions of reservation.

Moral consideration seems to be the most influential factor for opting for betrothal marriage among the Mafi people. A would-be spouse is expected to be of the high moral standard of the Mafi people. Both the man and the woman are expected to be of good character, respectful, hardworking and judged to be living a responsible life. Some people would do everything to avoid marrying from a family even perceived to have members who are noted for what the Mafi people consider evil acts. The moral standard of the individual is important but time is taken to scrutinise the family as a unit of the social structure and how this unit conforms to the norms and moral standards of the people.

A woman who is betrothed to a reputable person in the society commands the respect of the people. As explained by a discussant, betrothed ladies are normally protected from unnecessary advances of other men. It was possible in the past, without any special identification of the ladies, because the community was usually small with members knowing one another and participating in all communal activities. But at the same time, the woman also has the moral obligation to remain chaste until she is married off to the man. As betrothed couples are not wives and husbands until they are properly married, they are prevented from sexual relationship until after marriage. People may also offer or accept proposals for the betrothal marriage of their children in appreciation of honours and other services gained from the suitors. But it is also a fact that a girl may be betrothed to a man to settle debts owed by her parents to the suitor or the parents of the suitor. These cases can be regarded as objectification of women but it seems this concept of reification does not simply find place in Mafi thought. This aspect of marriage is simply explained as a factor for social cohesion.

The second type of marriage among the Mafi people is ahiasrodede or 'concubine marriage'. This is considered to be a form of marriage only when parents or families of the couple 
recognise or approve of the relationship between the couples. The desire and agreement to be in a marital relationship start with the couple living together as a married couple. The couple informs their parents and normally the man announces the relationship to the parents-in-law with drinks referred to as namanyaha. The couple continues to cohabitate until the full customary marriage rites are performed. However, if the man fails to inform the parents of the woman in order to reach a mutual agreement with them, he could be arrested and tried by the elders for unlawfully keeping the woman in his custody. Even in a situation where the parents of the woman are made aware of the relationship between their daughter and the man and the full customary marriage rites have not been performed before any untimely death of the woman, the man will still be held responsible for the failure to perform the full marriage customary rites.

The last of the categories of marriage among the Mafi is ahosrodede or 'widow marriage'. This refers to a remarriage of a widow. Generally, the widow can marry from within the family of the deceased husband or outside this family. There is, however, a kind of preferential marriage for widows in the form of 'levirate marriage'. The widow is normally betrothed to a younger brother of the deceased but never to an elder brother. A younger brother in traditional thought is qualified to inherit from the elder brother but not the other way round. In cases where there is no uterine younger brother or such a brother is not willing to marry the widow, a suitable man from the family will be required to marry her. A widow is obliged to complete the widowhood rites before she could sleep with a man.

Some explanations are given for widow marriage. Widows are retained in the family to prevent the disintegration of the bonds, earlier established through the marriage of the woman, with the husband's family. Further, the death of the man should not bring untold hardships to the widow and the children. At the same time, widow marriage ensures that transfer of property or inheritance to other families is avoided. New children raised in this marriage are in the name of the deceased husband and this 
keeps the name of the deceased in history. In widow marriage, the moral conduct of the widow in her past marriage can determine the success or failure of the marriage. For a widow to be retained in the deceased husband's family, she should be proven to be of good character, industrious and most importantly, that she has not committed any evil act against the deceased husband in particular and his family in general. The focus of evil acts against the husband is meant to determine whether the woman is involved in any way in the death of the husband. This is done through nukaka or consultation of the diviner. If she is found guilty, nobody in the family will accept to remarry her.

The process and ceremonies on marriage are elaborate and take a considerable length of time. An important aspect of the marriage rites is the coming together of the families of the couple. Marriage in Mafi, as in almost all African traditional societies, is not just between the marrying couples but between families. After initial agreements between the two families have been made, a day is set for the presentation and acceptance of drinks for the marriage. This is the sign of agreement or recognition of the marriage. Failure on the part of the man in particular to see to the presentation and acceptance of the drinks by the family of the woman would be viewed as unlawfully keeping of the woman in his custody. On the day of the marriage, various members of the family could voice any grievance or offences they might have suffered from the other family. There are elderly persons to give advice to the partners in the marriage, especially on marriage responsibilities and on how to sustain the marriage. This ceremony could be required posthumously from a man who did not perform it in the event of any untimely death of the woman. This should be done before burial and it is metaphorically described as the 'dawn of burial'.

\section{Marriage Rites at the Dawn of Burial}

The presentation and acceptance of the drinks for marriage have implications in terms of belief in soteriology and determination of responsible persons. In terms of soteriology, people are obliged to 
perform posthumous marriage rites for deceased persons. Posthumous marriage rites involve all the requirements of marriage with extra fines because they serve a punitive purpose. Traditionally in Mafi, it is husbands who are responsible for the performance of marriage rites. Therefore, the need for posthumous marriage rites can be traced to the attitude of the male spouse at the beginning of his union with the woman. There are broadly two categories of people who will require posthumous marriage rites. The first category is a woman whose husband did not perform the marriage rites before the death of the woman. In the case of these kinds of deceased persons, the posthumous marriage rites become highly necessary if the woman dies in the custody of the man. The man must necessarily inform the family of the woman about the untimely death of his partner and arrange for means to return the corpse to the family to initiate burial ceremonies. A man may come from the same community as the deceased, be closely related to the deceased's family, may have helped the deceased and relatives and even may have started the process of marriage rites but the fact that the process was not completed could call for posthumous marriage rites. The assumption on the part of the man that the parents of the deceased partner might be aware of their relationship would not be accepted as an excuse.

The second category of deceased persons that require marriage rites are persons - both male and female - whose father did not perform marriage rites for their mother in her life time. Because of the children sired, the man has no choice but to perform the posthumous marriage rites in order not to lose the paternity of the children. A man cannot perform any mortuary rites for a child got from a woman not married to the man in accordance with the traditional standards, custom and tradition of the people. While it appears that the need to restore deceased persons back to the family and the assertion of paternity would oblige a man to embrace posthumous marriage rites for his partner, there are other social and ethical reasons for the belief and practice of posthumous marriage in Mafi traditional society. One social conduct that undermines social cohesion in traditional societies is 
the undermining of the respect, dignity and integrity of the individual and/or the family. Families that do not keep to the cultural standards of the society could be taken for granted. For the sake of social cohesion, a family could be very reluctant to separate partners who have not performed the marriage rites. The woman's family may advise their daughter to persuade her husband to do the right thing while others could inform the man politely and informally about the need to perform the rites. However, if the woman passes on, the man has the most difficult task of redeeming the image of the woman's family. The physical and social manifestation of the sullied image of families can be discerned from insinuations and other derogatory remarks about children of parents who could not perform marriage rites. They may be taunted as hasiviwo 'concubine children' to mean illegitimate children. In Mafi parlance, this is derogatory and offensive.

In the social set-up, different mechanisms are employed to hold members responsible and accountable for certain values. The institution of marriage is held in such high esteem that the mechanisms for upholding the values inherent in the institution are made known to every member of the society. A condition for asserting and exhibiting marriage responsibility is the performance of the marriage rite. It is true that people, and for that matter, marriage partners are held responsible for the upbringing of their children, and men in particular for their wives, but the reaction to an individual caring for wives and children without initially performing the marriage rite is always negative. Such a person is considered irresponsible because the cost for caring for wives and children would surely be more demanding than the performance of the marriage rite. Proper marriage as symbolised in the performance of rites that can be used as a tool to hold individual members of the society responsible for the common good. In some cases, some members of the family of the deceased woman could refuse to co-operate with husbands of their daughters. This is an indirect way of indicating to the man that he is irresponsible. Therefore, to demonstrate one's social 
responsibility, gain the respect and integrity accorded married persons and also demonstrate maturity, a man must consider paying his ahaga bride price or bride worth even before taking the woman into his custody.

It equally behoves the prospective bride to ensure that her marriage partner performs the marriage rite. The woman could be ridiculed by her detractors, some family members and some people in the husband's family. In order to provoke separation, disgruntled members of the man's family may constantly taunt or remind the woman that her presence in their family is illegitimate. This occurs mostly in homes where the man is quite well-to-do or the family members are expecting the man to marry a particular woman of their choice. This attitude towards women from other families can be well appreciated if one considers the nonexogamous nature of marriage among the Tongu Mafi people. It is therefore the responsibility also of the woman to legitimise her presence within the family of the partner by convincing him to perform the rites. The last resort of the mechanisms worked out to ensure that the responsibility of performing marriage rites is not abused blatantly is the insistence on posthumous marriage rites. This also highlights the corporate responsibility that society imposes on families. It is incumbent on family heads to ensure that members of his family act in accordance with the norms of the society. The parents and family of the deceased man, who has failed to perform the marriage rites in his lifetime, are held responsible for the omission of their son.

There is a sense in which the reconstruction of social identity is linked with marriage rites. In African traditional societies, the family can also serve as the basic unit of the social organisation. The families are identifiable with certain features yet organically integrated with one another to form clans and society. Some peculiar character traits and vocation can be identified with certain families. But generally, family identity can be constructed through naming. Therefore, to reconstruct identity, people may change their names. In the experience of the Tongu Mafi people, it is often the practice that the woman's family gives a name to a 
child whose father has not performed the marriage rite, especially when the child is not in the custody of the father. In the course of this research, some students who have their names changed were interviewed. The recurring reason for the change of name was that their former names were given by their mothers' families. Their new names were the ones from their paternal families. Many of them affirmed that their mothers, and in some cases, their fathers had died. There were a few who indicated that their fathers were alive but they were brought up by the family of their mother. They changed their names from those given by the maternal family to that of the paternal family when their fathers accepted the responsibility to care for them. In this category of people, when they were asked, 'What kind of responsibility has your father accepted to do now?', the answers are generally that he has accepted to pay for their school fees and provide for their uniforms. As a matter of interest, many of these pupils and students interviewed were still living with their mothers or the families of their mothers. In a strict traditional practice, however, the father must necessarily pay for the ahaga or the final bride price or bride worth with a penalty before he can change the name of the child or take him or her into his custody.

The reconstruction of identities to belong especially to the paternal families can also be explained within the framework of the notion of inheritance. Tongu Mafi is a patriarchal and patrilineal society. In the traditional worldview of the people, the social identity of the individual or a group is linked up also with the notion of inheritance. The true sense of belonging to a family or a clan is to some extent woven around the right to inheritance. The individual can inherit the property of the father or through paternal lines. If a person has no claim to inheritance, the social standing and identity of such a person becomes questionable. In Mafi people's cultural practices, members of the family traced through maternal lines do not have the right to inheritance of family property. In this case, for example, a child cannot claim the mother's portion of land even though the mother might have inherited it from the paternal family. The child can have it only 
when it is given generously by the family. The property of the paternal family is often considered insufficient for the members. Hence, there is the saying among the Mafi people that etor $n u$ metuna ame abe enor nu ene o meaning 'the father's property (to be shared) is never enough as compared to the mother's property'. It is to the effect that only the humble and respectful child who can benefit from property in the maternal family. A child born out of illegitimate marriage can be denied the right to inheritance in both the paternal and maternal families. A responsible man, and for that matter his family, must foresee how and what his progenies could lose or be denied inheritance if marriages are not legitimised. In this respect, the family head reminds and ensures that members of the family live up to their responsibilities, especially those relating to marriage. The family head would not hesitate to perform posthumous marriage rites to forestall any possible denial of inheritance in the future. Two different but interrelated scenarios can be used to explain further the notion of inheritance and how they affect the practice of posthumous marriage rites. In one instance, parents, especially fathers, could be compelled to perform late marriage rites or posthumous rites because the deceased family member is well-to-do. In the second case, family members may consider posthumous marriage rite in order to claim the body and property of a rich deceased member. In both cases, the decisive consideration centres on the performance of marriage rites. In a situation where it is declared that the deceased person in question has a father, who did not perform marriage rite for the deceased's mother, the maternal family will lay claim to the property of the deceased.

The fact is also that the social identity of the individual or a group in the Tongu Mafi society is not limited to the world of the living or present world but extends to the world of spirits. As such, in a situation where a deceased person is buried by the wrong family, all efforts would be marshalled by the rightful family to exhume and rebury the body in the proper family cemetery. The claim to the body goes with the claim to the deceased's property. A man's family will consider all options including posthumous 
marriage rite to avoid any possible litigation and embarrassment. The notion that there is salvation when one joins the ancestors or gets to the ancestral home in the hereafter guides the living in the performances of their obligations so that access to the ancestors would not be denied them. Performing marriage rites should not be a barrier to the lofty belief of joining the ancestors or experiencing salvation after death. If a person is buried in a wrong cemetery, the soul of that person will not be at peace over there and will return to haunt the family until the right thing has been done. The proper performance of marriage rites therefore facilitates peaceful co-existence between the worlds of the living and the dead.

Mortuary rituals among the Tongu Mafi are meant to facilitate the peaceful transition of the dead to the spirit world. They accord the deceased great sense of respect and dignity. One such ritual for a deceased married man revolves around the widow. A man who has failed to perform the marriage rites of the woman in his life time could not have the widow to perform the rituals during and after his burial. Usually, it is the family of the woman who will prevent her from honouring the deceased with those rites. The alternative for the deceased's family is to resort to posthumous marriage rites in the name of the deceased. In this regard, the upright Mafi citizen shuns any acts which can bring about disrespect and indignity to oneself and community, before or after death, and therefore, regards the performance of marriage rites as a moral obligation.

\section{Sexuality and Procreation in Mafi Thought}

The moral codes of the Mafi people normally have something to do with the concepts of life and evil. Sexuality and procreation are explained in the context of sustaining life and preventing evil in the society. These concepts influence morality in marriage. The practice of polygamy is not a moral issue in the traditional philosophy of the Mafi people. Similarly, prostitution is never regarded as a threat to life or considered evil except that the practice is not cherished. On sexuality, there are taboos on 
places for having sexual intercourse (Nelson-Adjakpey, 1982, pp. 88-89). It is a taboo to have sex in the bush, in the farm or on the ground. These acts are considered a desecration of the earth. There is no earth deity in Mafi society but in prayers or libation, the earth is personified and deified. To the extent that the earth is viewed as sacred, these sexual misconducts as well as the unlawful spilling of blood and unauthorised activities at the cemeteries are considered desecration of the purity of the earth. Permission must be sought, through libation, from the earth and ancestors before any activity, such as burial or exhumation of corpses, is undertaken in the cemetery. Acts of sexual misconduct could lead to drought, famine and pestilence in the society unless purificatory rites are performed to cleanse the land of the desecration. Even married couples could not engage in these sexual misconducts. The institution of marriage then is a platform for expressing responsible sexuality and procreation to sustain life and society and guarantee harmony between the physical and spiritual realms.

As stated earlier, procreation is a moral obligation for persons considered adults and for married couples in particular. An individual or a couple could not decide to avoid giving birth. Divorce is usually not challenged if the reason is lack of procreation. Before a married partner would seek divorce, he or she might have been convinced that efforts to remedy barrenness or infertility through known avenues had failed. Most of the time, it is the women who are blamed for non-procreation. Although there are no statistics on divorce based on non-procreation, it is believed that women are quicker to divorce on these grounds than men. The difference is that male partners have the option to marry other women while the woman has the options of either staying in the marriage or asking for divorce. Infertility, impotence and barrenness are all perceived as evil because they are considered threats to life. Procreation is understood as the foundation for the sustenance of society and it is a moral obligation for every member of the society to contribute to this goal. Procreation therefore influences the sexual life of the Mafi people. For this reason, any marriage practices that will not lead to procreation are abhorred 
and considered evil in Mafi culture. In this regard, homosexuality is evil and unaccepted in Mafi society. In fact, except in modern and descriptive phraseology, there is no term for homosexuality in Mafi parlance. Similarly, zoophilia and necrophilia are abhorred and regarded as taboos. The practice of homosexuality, bestiality and necrophilia are all considered counter-productive to procreation, desecration of the institution of marriage and threat to life and society. A morally responsible person should not engage in any of these abhorred and abominable practices. So important is childbearing that there is a punitive mortuary rite for both adult men and women who fail to procreate irrespective of the cause of failure.

It is a fact that science and medical care have made significant impact on traditional outlook and broadened knowledge on reproductive health in Mafi society. However, in traditional belief system and worldviews, there is no recognition for the scientific explanations of infertility or barrenness as the basis for putting aside punitive post-mortem rites for nonprocreation by adults. Thus, known scientific causes of nonprocreation have, so far, not changed traditional worldviews on the moral obligation for every adult to procreate. While family planning and use of contraceptives may not raise any serious moral arguments, they may be considered negative in Mafi metaphysics if they lead to non-procreation by the average adult before any untimely death. Most often, the known scientific causes of non-procreation are subjected or traced to spiritual causations. Remarkably, it has never been the case for an individual to justify his or her inability to procreate. Neither have the rituals any gender discrimination.

On the other hand, there is no justification for abortion in Mafi thought. The emphasis is on induced abortion. The act of induced abortion is considered immoral, evil and ought not to be done on any condition. Since induced abortion is actually regarded as a destruction of life, the perpetrators, after death, are cremated as a punishment. The basis of this punitive and dissuasive mortuary rite is the failure of the individual to hold sacrosanct the 
moral obligation to procreate and sustain both family and society. Not only the individuals who caused induced abortion are held responsible for the perceived evil act, but all accomplices, including men, who were aware of and were in position to warn the perpetrators of the consequences of the act but failed to do so It is for this reason that elderly persons in the family, particularly parents in their private or intimate discussions with their children would advise them on the soteriological implications of choices the children make in their sexual life. Thus in marriage life, sexuality, procreation and moral responsibilities are anchored on soteriological ambitions.

\section{Moral Responsibility and Respect for Human Personality in Marriage}

In Mafi social and cultural practices, one form of outlook on morality is the individual and communal sense of responsibility. In Mafi thought, what a responsible person should do is self-evident; these are acts that promote peace, harmony and life, and they are internalised through socialisation processes right from childhood. Therefore, it is expected of every citizen to exhibit a sense of responsibility towards societal expectations. In the early stages of the process of marriage, parents and families would confidentially inquire from their children about their prospective suitors, asking: 'Do you know the person? Is he or she a responsible person?' It does not mean the parents are not aware of the character of the suitor but that they would like their children themselves to assess the sense of responsibility being exhibited by the suitor. It is also to remind the children that it would not be worthwhile to marry a morally irresponsible person who might also block her soteriological ambitions.

Further, married people have the responsibility to bring up their children according to the norms and traditions of the society. It is also the responsibility of the whole society to mould the character of children and inculcate discipline into them, even if parents tend to take the lead in exercising this responsibility. Apart from caring for their children, adults have the responsibility of 
supporting and caring for their aged parents. Married couples have the responsibility for the upkeep of the family. Women are mostly involved in domestic chores and are traditionally considered housewives. However, in childhood, both boys and girls are taught cooking responsibilities. Similarly, both boys and girls are introduced to farming in the agrarian settlements in the society. It is also a mark of responsibility for an adult citizen to be industrious and at the same time to own property. Both men and women can own property. They can decide on what to do with their property without restriction. However, society frowns upon 'evil' means of acquiring wealth or property. It is in this sense that some sources of wealth or acquired property are described as gafodi or 'dirty money'. Akpasusasa (i.e. the act of seeking wealth spiritually although the wealth manifests physically) is one form of 'dirty money' and source of wealth. It is also believed that a greedy person can spiritually tap into the sources of livelihood of other members of the society thereby destroying the tapped resources. For instance, it is believed that yields of crops can be transferred from the farm of an innocent person into the crops of the evil person through spiritual manipulation. Similarly, 'spiritual tapping' can be done to livestock.

To acquire wealth or property through these means is considered evil, irresponsible, and therefore, a threat to the wellbeing and life of members of the society. These evildoers are also punished with cremation after death. For the average Mafi person therefore, a morally responsible person, in order to achieve his/her soteriological goal of joining the ancestors, must refrain from these evil acts in spite of the pressures that marriage and family responsibilities may place on individuals. As a mark of moral responsibility, members of the community are to show bubu or respect for themselves and others. Respect must be shown in language or utterances, action and if possible in thought. Children are trained to internalise the use of mede kuku 'I beg' or 'please' in their discourse with parents or elderly persons. Mafi people support this value with the maxim, kukudevi wo me wui ne o, meaning 'a child who pleads (for mercy or forgiveness) is never 
killed'. A person who does not use courteous expression as part of his or her rhetoric could easily be discerned as a disrespectful person or one who has not acquired good moral training. It is understood in Mafi thought that a responsible person is normally a respectful person. Respect is only an aspect of showing responsibility.

In the family settings and in society in general, thoughts, utterances and actions of citizens must be kept within the bounds of courtesy and mutual respect for the personality and dignity of each other. The acknowledged respect for one another governs the behaviour of married couples, members of the family and the entire society. Behaviour which is normally not accepted in marriage life and family unit cannot also be accepted in the larger society. For cohesion in both the family and larger society, responsibility is placed on each member of the society to respect the personality and dignity of others. The sanctions for any violation of respect for the dignity of a person tend to be religious. They could be remedied if detected early or they could result in an untimely death. Furthermore, in marriage settings, the respect for oneself and others enjoins married couples and other family members to avoid animosity. In this sense, expressions of hatred and ill-feeling towards others, even if suppressed, as well as the exchange of vitriolic expressions are considered abominable acts for these could bring about spiritual sicknesses that would eventually lead to untimely deaths. It is again a mark of disrespect to others to use obscene and offensive language, especially, references to infirmities or disabilities and female genitalia as insults. These have religious sanctions. The overriding moral principle is for everyone in the society, especially married couples in their family units, to avoid evil acts. The moral responsibility to avoid evil is conceptually founded on traditional belief and worldview that evil acts conceptually affect soteriological ambitions. 


\section{Contemporary Dynamics}

Issues of marriage, sexuality and moral responsibility in contemporary societies may not be the same as they had been in traditional societies in the distant or immediate past. The advent of Christianity and the new frame it has provided on marriage, morality and notions of salvation serve as a factor of change. Christian practices have been widely adopted and these span the diverse departments of life including the various stages of life. In addition, formal education is often used to reinforce moral values entailed in Christian practices. It is also important to recognise the dispersal of Mafi citizens to other parts of the country for better economic opportunities by reason of the diversified economy of the country. As a result, citizens who have migrated to other parts of the country often sever ties with their homeland and the cultural values of their forebears. The cultural and religious encounters between Mafi society and the outside world could account for the changed dynamics in outlooks on marriage and moral responsibility. With cultural and religious encounters, some traditional practices and values have been abandoned, others toned down, new ones adopted, and in some cases blended. These have led to different levels of collaboration between different religions and cultural norms. The collaboration between Christians and traditionalists becomes clear on occasions of marriage and funeral ceremonies. The blending of moral values entailed in these ceremonies has perhaps been a significant unifying factor for the various religions.

However, based on the resilience of core indigenous beliefs and worldviews, moral values on marriage, sexuality and responsibility have been sustained. The pillar of the sustenance has been soteriological ambitions. At least, in the experience of the Tongu Mafi people of Ghana, practices and norms hinging on core indigenous beliefs and worldviews are quite resilient. Even in the face of globalisation, modifications to practices do not necessarily dislocate indigenous beliefs and practices. The ambition to join the ancestors or be one of them just by living a good life and the alternate post-mortem punitive rites leading to a 
dislocation of the soul in the ancestral home for being evil therefore affect individual choices in moral decision-making. This also seems to affect outlooks on life. For the Mafi person, and this can be said of many Ghanaians, blending of cultural values and adoption of new practices to deal with present challenges do not amount to a rejection of indigenous beliefs and worldviews. This has been the basis of creative hybridity in Mafi thought and practices.

\section{Conclusion}

As an institution and an integral part of individual and communal life and praxis, marriage can be described as a platform for the display of maximum moral obligation and responsibility among the Tongu Mafi people. In marriage then, the couple should exhibit the highest standard of responsibility to establish good esteem for themselves, family and society. What ought to be done or not done is founded on the moral responsibility to protect human life. Therefore, outlooks on marriage, sexuality, procreation and mutual respect by the couple and the upbringing of the child must all necessarily be in tune with the moral imperative of protecting human life. This would, however, not mean that the true exercise of moral responsibility is a preserve of only the married. It is required of all members of the society.

In Mafi metaphysics, beliefs and worldviews, the moral value of protecting the sanctity of life is couched in two moral principles: living a good life and avoiding evil. Living a good life translates into doing things that will not harm or negatively affect human life and the sanctity of life. On the other hand, avoiding evil is understood as desisting from acts and thoughts that can adversely affect or destroy human life, either by physical or spiritual means. Evil in Mafi philosophy is defined as what can destroy or maim the quality of human life. These two moral principles must be observed simultaneously in life. The emphasis on these moral principles is important for it constitutes the foundation of soteriological concerns of the Tongu Mafi people. 
While the social function of marriage is obvious in Mafi society, a critical analysis of the connubial practices reveals its interconnection with soteriological beliefs and ambitions. For this reason, sanctions against breaches of moral obligation and responsibility on marriage and sexuality, especially those that are life-threatening, tend to be religious. They also have soteriological implications. The average Tongu Mafi adult who understands his or her cultural values would certainly aspire to be an ancestor or at least attain salvation by getting into the ancestral home. Some of the post-mortem rites are not merely punitive but an attempt to prevent the souls of such evil persons from ever getting to the ancestral home and at the same time redirect them to their assigned section of the spirit world. Therefore, the average and discerning Tongu Mafi person in his or her moral decision-making on choices of marriage life, sexuality, procreation and taking care of the child would not overlook the soteriological concerns in life. 


\section{References}

Ahortor, G. (2015). Soteriological beliefs and ethical values of the Tongu Mafi people. ( $\mathrm{PhD}$ thesis). University of Ghana, Legon. Dzobo, N. K. (1985). African ancestral cult: A theological appraisal. Reformed World, 38,334-340.

Gaba, C. (1978).Man's salvation: Its nature and meaning in African traditional religion. In E. Fashole-Luke, R. Gray, A. Hastings \& G. Tasie (Eds.), Christianity in independent Africa (pp. 389-401).. London, UK: Rex Collins.

Gyekye, K. (1996). African cultural values: An introduction. Accra, Ghana: Sankofa Publishing Company.

Mbiti, J. S. (1989). African religions and philosophy ( $\left.2^{\text {nd }} . e d\right)$. London, UK: Heinemann.

Meyer, B. (1999).Translating the devil: Religion and modernity among the Ewe in Ghana. Edinburgh, UK: Edinburgh University Press.

Nelson-Adjakpey, T. (1976). Penance and expiatory sacrifice among the Ghanaian-Ewe and their relevance to Christian religion. Rome, Italy: Tipografia Olimpica.

Nukunya, G. K. (1969). Kinship and marriage among the Anlo Ewe.London, UK: Athlone Press.

Nukunya, G. K. (2003).Tradition and change in Ghana: An introduction to sociology. Accra, Ghana: Ghana Universities Press.

Sarpong, P. K. (1971).A theology of ancestors. Insight and Opinion, 5(2), 1-9.

Submitted: March 21, 2016/ Published: October 31, 2016 